\title{
A method for multi-hazard mapping in poorly known volcanic areas: an example from Kanlaon (Philippines)
}

\author{
M. Neri ${ }^{1}$, G. Le Cozannet ${ }^{2}$, P. Thierry ${ }^{2}$, C. Bignami ${ }^{3}$, and J. Ruch ${ }^{4}$ \\ ${ }^{1}$ Istituto Nazionale di Geofisica e Vulcanologia, Sezione di Catania, Catania, Italy \\ ${ }^{2}$ Bureau de Recherches Géologiques et Minières, Orléans, France \\ ${ }^{3}$ Istituto Nazionale di Geofisica e Vulcanologia, Centro Nazionale Terremoti, Rome, Italy \\ ${ }^{4}$ Dipartimento di Scienze, Università Roma Tre, Rome, Italy
}

Correspondence to: M. Neri (marco.neri@ct.ingv.it)

Received: 11 December 2012 - Published in Nat. Hazards Earth Syst. Sci. Discuss.: Revised: 25 May 2013 - Accepted: 29 May 2013 - Published: 1 August 2013

\begin{abstract}
Hazard mapping in poorly known volcanic areas is complex since much evidence of volcanic and non-volcanic hazards is often hidden by vegetation and alteration. In this paper, we propose a semi-quantitative method based on hazard event tree and multi-hazard map constructions developed in the frame of the FP7 MIAVITA project. We applied this method to the Kanlaon volcano (Philippines), which is characterized by poor geologic and historical records. We combine updated geological (long-term) and historical (shortterm) data, building an event tree for the main types of hazardous events at Kanlaon and their potential frequencies. We then propose an updated multi-hazard map for Kanlaon, which may serve as a working base map in the case of future unrest. The obtained results extend the information already contained in previous volcanic hazard maps of Kanlaon, highlighting (i) an extensive, potentially active $\sim 5 \mathrm{~km}$ long summit area striking north-south, (ii) new morphological features on the eastern flank of the volcano, prone to receiving volcanic products expanding from the summit, and (iii) important riverbeds that may potentially accumulate devastating mudflows. This preliminary study constitutes a basis that may help local civil defence authorities in making more informed land use planning decisions and in anticipating future risk/hazards at Kanlaon. This multi-hazard mapping method may also be applied to other poorly known active volcanoes.
\end{abstract}

\section{Introduction}

A hazard map is one of the most useful decision-making support tools for risk management in volcanic areas (Newhall and Hoblitt, 2002). It is commonly used by authorities to provide specific recommendations to regulate human settlement and as a guideline for land use planning. The term "hazard maps" sometimes refers to a spatial representation of the maximum extent of a given adverse event, but this decisionsupport tool is more commonly called a "susceptibility map". In this paper, we define hazard as the probability that adverse events reach a given intensity (i.e. destructive potential) over a given period of time (Table 1). In this sense, hazard is a synonym of "threat", and it can exceed a given threshold (1) either because adverse events of rather moderate intensity can occur frequently, (2) or because the probability of occurrence of adverse events is lower and their intensity higher. Hazard assessment thus requires the evaluation of two properties of adverse events: their intensity and their probability of occurrence (e.g. Thierry et al., 2008). Similar definitions are commonly used in the field of risk assessment (e.g. Vecchia, 2001; Douglas, 2007; Neri et al., 2008; Marzocchi et al., 2009; Crisci et al., 2010; Vicari et al., 2011) and elsewhere (IPCC, 2012).

Civil security and responsible authorities in the field of risk management are becoming increasingly concerned with the evaluation of the full spectrum of threats that may affect a given region. For this purpose, scientists have developed multi-hazard assessments methods (Kappes et al., 2012), for which one key difficulty is to compare and aggregate 
Table 1. Key vocabulary used in this paper and associated definitions.

\begin{tabular}{|c|c|c|}
\hline Term & Definition used in this study & Example \\
\hline Adverse event & Event likely to cause damage. & pyroclastic density current, lahars, tephra fall, etc. \\
\hline Phenomenon & $\begin{array}{l}\text { One of the forms under which } \\
\text { the adverse event may cause damage. }\end{array}$ & $\begin{array}{l}\text { static vertical loading on roofs, chemical } \\
\text { aggression on crops caused by tephra fall, etc. }\end{array}$ \\
\hline Physical effects & $\begin{array}{l}\text { Each type of phenomenon is characterized by } \\
\text { one or more intrinsic physical effects } \\
\text { expressed through physical units. }\end{array}$ & $\begin{array}{l}\text { cinematic impact expressed in } \mathrm{J} \text {, } \\
\text { pressure or loading in } \mathrm{Pa} \text {, thickness in } \mathrm{m} \text {, } \\
\text { peak ground acceleration in } \mathrm{ms}^{-2} \text {, etc. }\end{array}$ \\
\hline Physical intensity & Destructive potential of an adverse event. & water height, velocity and direction of a tsunami. \\
\hline $\begin{array}{l}\text { Physical intensity } \\
\text { scale }\end{array}$ & $\begin{array}{l}\text { Scale defined from physical values that express } \\
\text { the magnitude class of a physical effect (Table 2). }\end{array}$ & $\begin{array}{l}\text { scale for load: } 1-3 \mathrm{kPa} \text { low intensity, } \\
\text { from } 3 \text { to } 5 \mathrm{kPa} \text { moderate intensity, etc. }\end{array}$ \\
\hline $\begin{array}{l}\text { Frequency and } \\
\text { return period }\end{array}$ & $\begin{array}{l}\text { The estimated return period between two } \\
\text { adverse events of the same type and intensity } \\
\text { in a given sector is defined as the inverse of } \\
\text { its probability of occurrence each year. } \\
\text { With this approach, return periods are classified } \\
\text { in a few bins, here called frequency classes (Table } 3 \text { ). }\end{array}$ & $\begin{array}{l}\text { a centennial event has a probability } \\
\text { of } 0.01 \text { of occurring each year }\end{array}$ \\
\hline Hazard & $\begin{array}{l}\text { The probability that adverse events reach } \\
\text { a given intensity over a period of time. }\end{array}$ & $\begin{array}{l}\text { Threat indexes associated with recommendations } \\
\text { for the prevention of risks (see Table 5). }\end{array}$ \\
\hline
\end{tabular}

different kinds of hazards (e.g. Grunthal et al., 2006). This issue is particularly acute in volcanic areas, since they may be affected by numerous volcanic and non-volcanic adverse events (Fig. 1). Indeed, phreatic and magmatic eruptions may produce tephra fall, pyroclastic density currents, lava flows, blasts, sector collapses, gas emissions, lahars, landslides, rockfalls, floods, earthquakes, coseismic and aseismic faulting, and, in some cases, tsunamis. Each of these adverse events can be characterized by one or several phenomena potentially causing various kinds of physical effects (Fig. 1). For example, a single adverse event like tephra fall may cause damages by several phenomena: static vertical loading on roofs, burial of roads, dust concentration, and chemical aggression to crops. The corresponding physical effects can be expressed through various physical units (e.g. Pa, pressure; $\mathrm{m}$, thickness; ppmv, dust concentration; $\mathrm{pH}$, acidity), and each kind of exposed asset can be impacted in various ways, so that a standardized common intensity scale is particularly difficult to define.

In addition, volcanic eruptions are not the only cause of damage in volcanic areas. For example, lahars and mudflows may not only occur during volcanic unrest, but also may be triggered by heavy rains, months after the eruption, as at Pinatubo in 2001 (Hayes et al., 2002) and more recently at Merapi volcano in 2010 (Lavigne et al., 2011; Bignami et al., 2013). On Mount Cameroon, landslides that are not related to contemporary volcanic activity are a major concern (Ayonghe et al., 2004). On Etna and Stromboli, several zones are affected by landslides at various scales, triggered by vol-

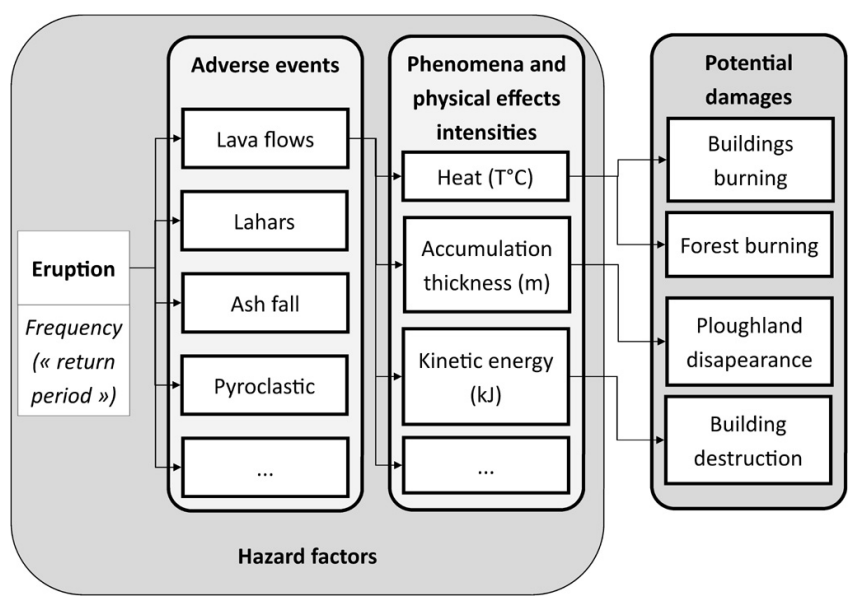

Fig. 1. Scheme showing an example of factors to take into account for hazard mapping according to the proposed method.

canic activities and/or by seismicity (Acocella et al., 2006b; Neri et al., 2008; Solaro et al., 2010; Barreca et al., 2013). In a multi-hazard assessment procedure, it is thus necessary to equally consider the adverse events that may occur during both the rest and unrest periods.

For risk management purposes, there is a need for multihazard maps that translate the combination of multiple threats into recommendations for populations, authorities and for land use planning. On the basis of a geological field survey at Mount Cameroon, Thierry et al. (2008) showed an 
Table 2. Intensity baseline for all adverse events related to human life (adapted from Stieltjes, 1997).

\begin{tabular}{lccc}
\hline $\begin{array}{l}\text { Intensity } \\
\text { class }\end{array}$ & $\begin{array}{c}\text { Qualification } \\
\text { of the hazard } \\
\text { intensity }\end{array}$ & $\begin{array}{c}\text { Degree of damage } \\
\text { with respect to } \\
\text { maximum human impact }\end{array}$ & $\begin{array}{c}\text { Numerical } \\
\text { equivalent }\end{array}$ \\
\hline$I_{1}$ & very low to negligible & social and economic hardship & 0.5 \\
$I_{2}$ & low & slight injury & 2.5 \\
$I_{3}$ & moderate & severe injury & 15 \\
$I_{4}$ & high & severe injury potentially leading to death & 60 \\
$I_{5}$ & very high & maximum corresponding to loss of life & 100 \\
\hline
\end{tabular}

Table 3. Frequency baseline for all adverse events.

\begin{tabular}{lcrrr}
\hline $\begin{array}{l}\text { Frequency } \\
\text { class }\end{array}$ & $\begin{array}{c}\text { Qualification } \\
\text { of the event } \\
\text { frequency }\end{array}$ & $\begin{array}{r}\text { Return period for the type } \\
\text { of activity or phenomenon } \\
\text { (order of magnitude) }\end{array}$ & $\begin{array}{r}\text { Quantification of } \\
\text { the phenomenon } \\
\text { frequency } Q_{f}\end{array}$ & $\begin{array}{r}\text { Index used for } \\
\text { the threat matrices } \\
\left(Q_{F}=100 \cdot Q_{f}\right)\end{array}$ \\
\hline$F_{0}$ & very low to negligible & $\begin{array}{r}5000-10000 \mathrm{yr} \\
1000-5000 \mathrm{yr}\end{array}$ & $10^{-4}$ & 0.01 \\
$F_{1}$ & very low & $500-1000 \mathrm{yr}$ & $10^{-4}$ & 0.02 \\
$F_{2}$ & low & $100-500 \mathrm{yr}$ & $2 \times 10^{-3}$ & 0.1 \\
$F_{3}$ & moderate & $50-100 \mathrm{yr}$ & $10^{-2}$ & 0.2 \\
$F_{4}$ & high & $10-50 \mathrm{yr}$ & $2 \times 10^{-2}$ & 2 \\
$F_{5}$ & very high & $1-10 \mathrm{yr}$ & $10^{-1}$ & 10 \\
$F_{6}$ & quasi-permanent & & & 1 \\
\hline
\end{tabular}

example of how a multi-hazard map can be drawn considering several types of adverse events: in their studies, six volcanic and three other geological adverse events were considered. While their approach enables drawing multi-hazard maps for a volcano where relatively few eruptive styles are known (Zogning, 1988), a structured procedure is required for more complex volcanoes with numerous and very different possible eruptive scenarios. To this end, Newhall and Hoblitt (2002) proposed building event trees, which have been applied for example by Marzocchi et al. (2004) to Vesuvius, and then used by Neri et al. (2008) and Martì et al. (2008) to provide a volcanic hazard map at Vesuvius and Teide-Pico Viejo, respectively. Finally, a Bayesian event tree to estimate volcanic hazard (BET_VH) has recently been published by Marzocchi et al. (2010) and applied at Campi Flegrei volcanic field, in southern Italy (Selva et al., 2010). This method calculates the probability of any kind of longterm adverse event for well-known volcanoes.

The goal of this paper is to provide an applicable hazard mapping method in volcanic areas characterized by a minimum level of geological data and historical records. The method (Sect. 2) combines the Thierry et al. (2008) multi-hazard mapping approach and the Neri et al. (2008) event-tree-based method. We applied the new designed semiquantitative method to the active Kanlaon volcano (Negros island, south-east Philippines), characterized by frequent phreatic eruptions during the past $120 \mathrm{yr}$ (Sect. 3). We propose (1) a simplified event tree for future unrest episodes at Kanlaon implemented by new morphostructural data, (2) an upgrade of the existing hazard maps, and finally (3) a new multi-hazard map. In Sect. 5, we discuss the relevance and limitation of our approach, the implications for people at risk at Mount Kanlaon and the potential transportability of the approach to other poorly known volcanoes.

\section{Method}

This part explains the principle of the proposed hazard mapping method.

\subsection{Definition and use of reference intensity and frequency scales}

Hazard assessment implies choosing a parameter that may exceed a certain threshold over a given period of time (Douglas, 2007). It is generally based on expert opinion, as well as empirical and physical models (Vecchia, 2001). As raised in the introduction, the main difficulty here is that many adverse events and related phenomena are characterized by very different parameters. For example, a building can be affected by peak ground acceleration induced by earthquakes (Barreca et al., 2013), pressure on its roof induced by tephra fall may also lead to its collapse (Spence et al., 2005). Agriculture may be impacted by tephra fall rather more than other factors, while, notwithstanding more destructive adverse events, human health may be affected by $\mathrm{SO}_{2}$ concentration in the air when people are exposed beyond a certain period (Klose, 2007). Therefore, when attempting to perform a multi-hazard 
assessment, the different parameters cannot be readily projected onto a unique baseline built on a single physical parameter. Hence, a key step of multi-hazard mapping is to define common intensity and frequency reference baselines to evaluate the various hazards (Tables 2 and 3; Kappes et al., 2012).

Following the principles of the European Macroseismic Scale (EMS 1998), we propose here a reference intensity baseline that relates the intensity of phenomena, whatever their nature, to their average expected impact on human beings (here adapted from Boiteux and Baumstark, 2001). The principle of our intensity baseline is to refer to the potential destructive effects of the respective kind of adverse events. For example, experts can refer to this baseline as follows: knowing the average quality of buildings in a given volcanic area such as Mount Cameroon and considering the characteristics of buildings in the areas, it can be expected that a pressure of less than $1 \mathrm{kPa}$ induced by tephra fall (Spence et al., 2005; Thierry et al., 2008) or an earthquake of magnitude V-VI on the EMS 1998 scale would cause light damage to many buildings. Therefore, both phenomena would correspond to the same intensity class $I_{2}$ (low intensity) on the scale in Table 2. Conversely, a static load exceeding $2 \mathrm{kPa}$ will lead to roof collapses triggering severe injuries and possible deaths. In this second case, the intensity class will be $I_{4}$ or $I_{5}$ (high or very high intensity) In practice, the relation between physical effect and intensity is site-dependent due to local vulnerability and must be set up for each volcanic area: for example, on a region where many buildings' roofs are made of concrete, the same intensity class $I_{3}$ could correspond to a static pressure of tephra of 4-6 $\mathrm{kPa}$.

The frequency baseline used in this paper is presented in Table 3. Similarly to the approach in Thierry et al. (2008), experts can refer to historical or geological evidence or any other source of information to provide their best guesses of frequency of adverse events according to Table 3. The relatively coarse resolution of the frequency baseline has been constructed in a way that the return period of each eruptive mode of the volcano can be approximately appraised, even if limited knowledge of the volcano's history is available.

Finally, cross-referencing the intensity and the frequency of events leads to defining a common threat matrix (Table 4), which allows building a hazard scale corresponding to practical recommendations for human settlement (Table 5). Although referring to a common intensity scale, we do not integrate any local information about the vulnerability of assets or their exposure. Therefore, we evaluate neither risk (as a combination of hazard and vulnerability of exposed assets) nor individual risk (as defined by Marzocchi and Woo, 2009). Here, the only purpose of analysing the potential impact of phenomena is to enable reference to a common metrics, available for all types of phenomena. Therefore, the threat index provided here is a proxy of the hazard and does not integrate the actual vulnerability of assets at risk.
Table 4. Threat matrix obtained crossing intensity and frequency baselines; values indicate possible thresholds for recommendation options (see Table 5): in this illustrative example, 0.005-0.05: negligible hazard; 0.1-3: moderate hazard; 5-60: high hazard; > 100: very high hazard.

\begin{tabular}{rlccccc}
\hline Frequency & Intensity & $\begin{array}{c}0.5 \\
I_{1}\end{array}$ & $\begin{array}{c}2.5 \\
I_{2}\end{array}$ & $\begin{array}{c}15 \\
I_{3}\end{array}$ & $\begin{array}{c}60 \\
I_{4}\end{array}$ & $\begin{array}{c}100 \\
I_{5}\end{array}$ \\
\hline $10^{-4}$ & $F_{0}$ & 0.005 & 0.025 & 0.15 & 0.6 & 1 \\
$2 \times 10^{-4}$ & $F_{1}$ & 0.01 & 0.05 & 0.3 & 1.2 & 2 \\
$10^{-3}$ & $F_{2}$ & 0.05 & 0.25 & 1.5 & 6 & 10 \\
$2 \times 10^{-3}$ & $F_{3}$ & 0.1 & 0.5 & 3 & 12 & 20 \\
$10^{-2}$ & $F_{4}$ & 0.5 & 2.5 & 15 & 60 & 100 \\
$2 \times 10^{-2}$ & $F_{5}$ & 1 & 5 & 30 & 120 & 200 \\
$10^{-1}$ & $F_{6}$ & 5 & 25 & 150 & 600 & 1000 \\
\hline
\end{tabular}

\subsection{Knowledge collection at a target volcano and event tree construction}

We start the actual analysis of the volcanic site by collecting knowledge on the studied volcano through field studies and analysis of historical events (Fig. 2). This step is used to determine and characterize reference eruptions of the volcano, e.g. in terms of explosivity (Newhall and Self, 1982) and/or eruption rate, duration and volume of the lava flows (in the case of mainly effusive volcanoes; Crisci et al., 2010; Vicari et al., 2011). Then, event trees can be created and used as a support tool to structure the quantification of each phenomenon and their frequency of occurrence (Newhall and Hoblitt, 2002).

Attributing a probability to each node of the event tree is the most problematic task: in order to do this, Aspinall (2006), Martí et al. (2008) and Neri et al. (2008) proposed an elicitation-based approach to build an event tree for Montserrat (Caribbean islands), Teide-Pico Viejo (Canary Islands) and Vesuvius (Italy). This involves a structured collection of expert guesses together with the associated uncertainties. This approach may be applied for case studies such as at Vesuvius, where a large amount of information is available on past volcanic events thanks to historical reports since Roman times, and numerous sedimentology studies (Acocella et al., 2006a; Gurioli et al., 2010, and references therein). In less known volcanoes is an approach that could become more widespread with the sharing and dissemination of historical eruption data (Marzocchi et al., 2004; Sandri et al., 2012). Even when little is known about past eruptions, Thierry et al. (2008) showed through the hazard mapping study of Mount Cameroon that the probabilities can still be approximately determined using the best guesses of experts. However, it should be noted that, in Thierry et al. (2008), the event tree was not explicitly drawn because there were very few eruptive modes to consider in practice. In any case, in many poorly known volcanoes, probabilities would therefore be the result of experts' best guesses based on ground 
Table 5. Example of possible generic recommendations associated with each hazard level.

\begin{tabular}{ll}
\hline Hazard level & Associated recommendation \\
\hline Negligible hazard & No recommendation for normal permanent human settlements. \\
Low hazard & No specific recommendation, but a certain vigilance is required, in particular for the exposed elements of great or primordial importance. \\
Moderate hazard & Permanent human settlement is possible, but specific precautions are recommended, depending on the phenomena involved. \\
High hazard & Permanent human settlement is inadvisable, unless major precautions are taken. \\
Very high hazard & Permanent human settlement should be avoided. \\
\hline
\end{tabular}

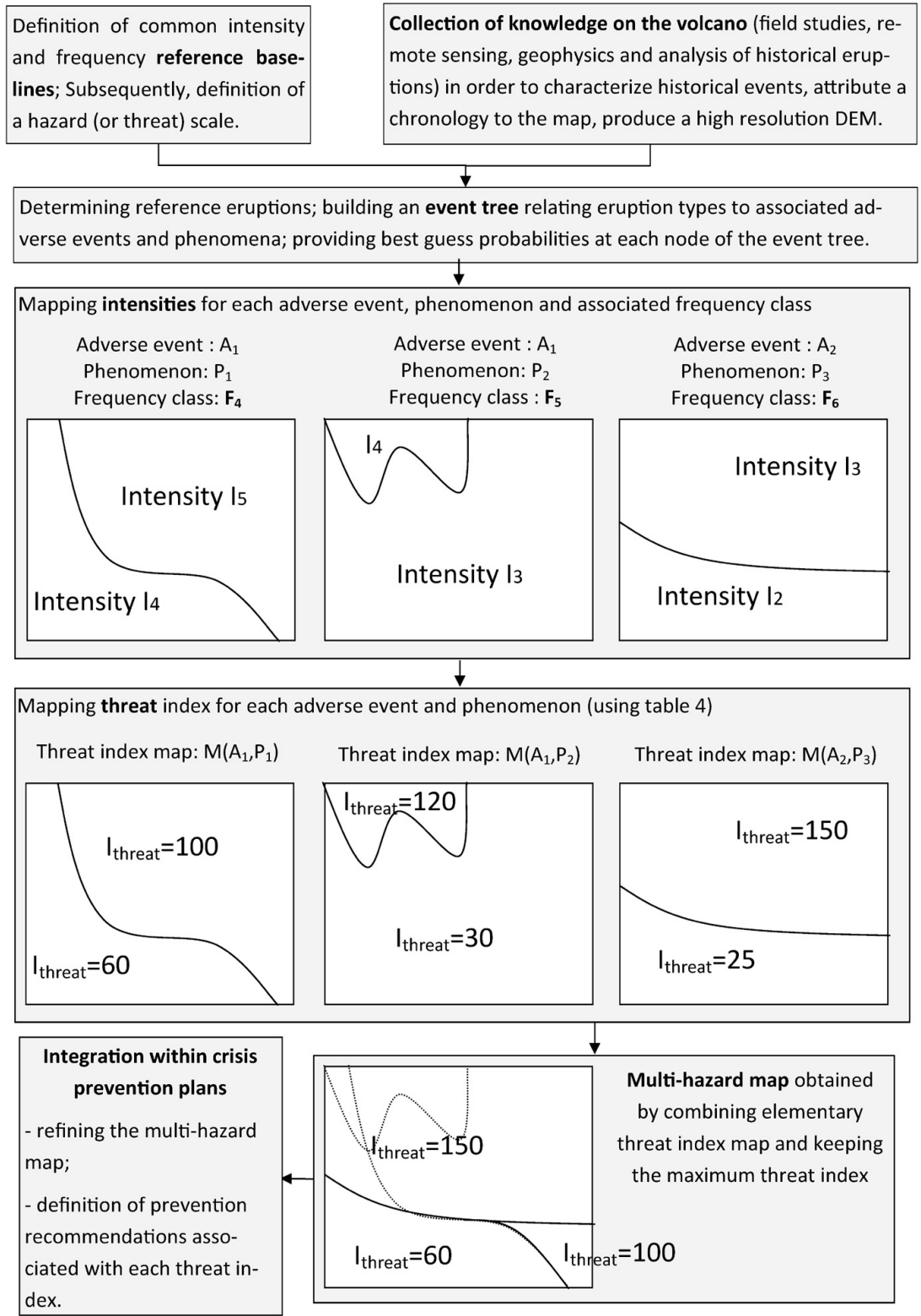

Fig. 2. Rationale of the proposed hazard mapping method. The method starts with the definition of intensity and frequency baselines (Sect. 2.1) and collection of knowledge on the volcano (Sect. 2.2). The analysis of eruption types, adverse events, phenomena and their probability of occurrence is organized around the development of an event tree; this enables mapping intensity, threat indexes and combining them within a single multi-hazard map (Sect. 2.3). In a further step, the hazard map should be integrated within risk management plans. 
geological evidence, historical records, as well as possible numerical modelling.

\subsection{Event tree output, intensity and multi-hazard mapping}

The purpose of using the event tree is to provide a framework to estimate the frequencies and intensities of phenomena associated with the various kinds of eruption modes. In the next step of the method, those frequencies are calculated using the probabilities inserted in the event tree. Given an eruptive mode (i.e. at the latest node of the event tree), the expected intensities of each phenomenon corresponding to each adverse event must then be mapped. Here, experts may similarly use their best guesses, referring to geological and geomorphological evidence (e.g. topography location of potential eruptive vents, etc.), historical reports or the behaviour of similar volcanoes. At this step, sectors affected by eruptive events may be determined to take into account topographical or wind (for gas and tephra fall) constraints that might affect the hazard map (Neri et al., 2008).

For each reference eruption, a threat index corresponding to each type of eruption and each phenomenon is then calculated at each location by multiplying the frequency and intensity indexes (Fig. 2). Mapping the threat index on the sectors defined in the previous phase may provide a first set of threat maps, e.g. one map per adverse event. In practical terms, as a consistent scale has been used for all types of adverse events, a multi-hazard map can be produced by simply keeping the maximum threat index at each location. Choosing the maximum index here is therefore equivalent to selecting the prevention option (Table 5) according to the type of adverse event causing the most important threat at each location.

This multi-hazard map can finally be improved using geological structural and topographical evidence, field observations and modelling (e.g. lahar flows). Lastly, a step that involves the local authorities is to define recommendations associated with each level of hazard (Fig. 2).

\section{Application of the model to Kanlaon volcano}

In the following, we apply and test the proposed semiquantitative method to the construction of a multi-hazard map on Kanlaon volcano (Negros island, Philippines, Fig. 3).

\subsection{Geological and morphostructural update at Kanlaon}

The stratovolcano Kanlaon is one of the 23 active volcanoes belonging to the Philippine archipelago (Rae et al., 2004). The Negros volcanic belt, which is part of the Philippine Microplate, extends $\sim 260 \mathrm{~km}$ in N-S direction and hosts six main volcanic edifices, four of which are active and located on Negros island (Fig. 3). One of these, Kanlaon

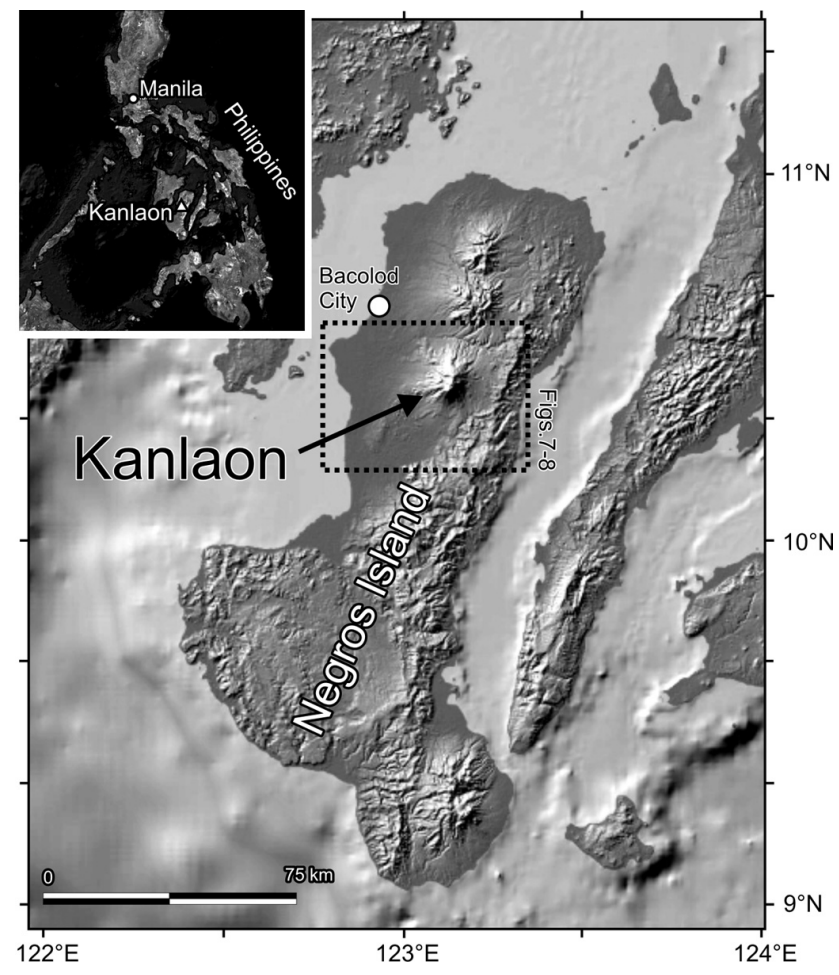

Fig. 3. Location of the study area.

(2435 m), has a calc-alkaline andesite and basaltic andesite composition (Von Biedersee and Pichler, 1995; Solidum et al., 2003); it is located approximately $33 \mathrm{~km} \mathrm{SE}$ of Bacolod City (511 820 inhabitants according to the 2010 census), and is surrounded by several minor towns (more than 300000 inhabitants in all within the volcano's vicinity).

The present volcanic activity of Kanlaon (Table 6) is characterized by (1) frequent phreatic and phreatomagmatic eruptions (VEI =1-2) with 29 events recorded since 1866 (Simkin et al., 1981; Von Biedresee and Pichler, 1995; Siebert et al., 2010), (2) effusive and Strombolian eruptions, the only known event occurred in $1902(\mathrm{VEI}=2)$, and (3) explosive eruptions emplacing pyroclastic flows (VEI $\geq 2$ ), the last took place $<2.5 \times 10^{2} \mathrm{yr}$ ago on the south western flank of the volcano (Siebert et al., 2010).

To improve our geologic knowledge of Kanlaon, we studied the volcanic succession through field observations, remote sensing data with a $15 \mathrm{~m}$ resolution LANDSAT $7 \mathrm{im}$ age (2003), and a $2.5 \mathrm{~m}$ resolution stereo pair from the Panchromatic Remote-sensing Instrument for Stereo Mapping (PRISM) on board the Japanese satellite ALOS (Advanced Land Observing Satellite, 2009). This image pair, acquired in December 2009, has been used to derive a new digital elevation model (DEM) with $10 \mathrm{~m}$ pixel resolution on ground. The results allow distinguishing two main angular unconformities bounding three main groups of stratigraphic units.

The oldest unit (Kumalisquis volcanics in Fig. 4) crops out in the NE and $\mathrm{E}$ portions of the apparatus; this succession 
Table 6. Historical eruptive activity of Mt Kanlaon volcano (modified after Siebert et al., 2010, and reports available at http://www.phivolcs. dost.gov.ph).

\begin{tabular}{|c|c|c|c|c|c|}
\hline Onset & End & Volcanic activity & VEI & $\begin{array}{c}\text { Sectors } \\
\text { affected } \\
\text { by ashfall }\end{array}$ & Notes \\
\hline 1866 & 1866 & explosive/phreatic & 2 & & \\
\hline Jul 1883 & Jul 1883 & explosive/phreatic & 2 & & \\
\hline May 1884 & Jun 1884 & explosive & 2 & & \\
\hline Jul 1893 & 1893 & explosive/phreatic & 2 & $\mathrm{E}$ & \\
\hline May 1894 & Jun 1894 & explosive & 2 & & \\
\hline 31 Jan 1902 & 1902 & explosive/effusive & 2 & & \\
\hline 1904 & 1904 & explosive/phreatic & 2 & & \\
\hline 6 Nov 1905 & 16 Jan 1906 & explosive/phreatic & 2 & & \\
\hline 20 Mar 1927 & 1927 & explosive/phreatic & 2 & SE & \\
\hline Dec 1932 & Jan 1933 & explosive/phreatic & 2 & & \\
\hline 10 Oct 1969 & 29 Oct 1969 & explosive/phreatic & 2 & & $6 \mathrm{~km}$ high eruption column, mudflows and lahars \\
\hline 5 Jun 1970 & 24 Aug 1970 & explosive/phreatic & 1 & & \\
\hline 27 Jun 1978 & 2 Sep 1978 & explosive/phreatic & 2 & & $1.8 \mathrm{~km}$ high eruption column \\
\hline 8 Aug 1980 & 1980 & explosive/phreatic & 2 & & \\
\hline 13 Mar 1985 & 14 Mar 1985 & explosive/phreatic & 1 & SW & $<1 \mathrm{~km}$ high eruption column \\
\hline 5 Oct 1985 & 7 Dec 1985 & explosive/phreatic & 1 & & \\
\hline 3 Jun 1986 & 18 Aug 1986 & explosive/phreatic & 2 & SE & $4 \mathrm{~km}$ high eruption column \\
\hline 30 Mar 1987 & 2 Jul 1987 & explosive/phreatic & 1 & SW & \\
\hline 21 Jun 1988 & 2 Jul 1988 & explosive/phreatic & 1 & & $1 \mathrm{~km}$ high eruption column \\
\hline 25 Oct 1989 & 13 Dec 1989 & explosive/phreatic & 2 & SE & $1.2 \mathrm{~km}$ high eruption column \\
\hline 14 Feb 1991 & 14 Feb 1991 & explosive/phreatic & 2 & & \\
\hline 8 Jan 1992 & 8 Jan 1992 & explosive/phreatic & 1 & SW & $1 \mathrm{~km}$ high eruption column \\
\hline 10 Jun 1992 & 10 Jun 1992 & explosive/phreatic & 2 & & \\
\hline 25 Aug 1993 & 3 Sep 1993 & explosive/phreatic & 2 & ESE & $1 \mathrm{~km}$ high eruption column \\
\hline 10 Aug 1996 & 10 Aug 1996 & explosive/phreatic & 2 & & $1.5 \mathrm{~km}$ high eruption column, 3 casualties \\
\hline 28 Nov 2002 & 28 Nov 2002 & explosive/phreatic & 2 & & \\
\hline 7 Mar 2003 & $23 \mathrm{Jul} 2003$ & explosive/phreatic & 1 & ESE & $1.5 \mathrm{~km}$ high eruption column \\
\hline 25 Jan 2005 & 25 May 2005 & explosive/phreatic & 2 & $\mathrm{E}, \mathrm{SE}$ & $1 \mathrm{~km}$ high eruption column \\
\hline 3 Jun 2006 & $25 \mathrm{Jul} 2006$ & explosive/phreatic & 2 & SE, S, SW & $2 \mathrm{~km}$ high eruption column \\
\hline
\end{tabular}

culminates with the La Castellana debris avalanche deposit ( $<0.4 \mathrm{Ma}, 13 \mathrm{~km}^{3} \mathrm{Ma}$; V. Antonia Bornas, personal communication, 2010), resulting from a massive flank collapse of the volcano that travelled $33 \mathrm{~km}$ to the SW, covering an area exceeding $300 \mathrm{~km}^{2}$. This is the most remarkable and dramatic known event affecting Mt Kanlaon. The debris is very probably linked to an erosive amphitheatre today filled in by later volcanic activity, whose limits are still somewhat recognizable for the existence of buried morphological scarps (see unconformity 1 in Fig. 4).

The intermediate unit (La Carlota volcanics) is bounded at the bottom by the unconformity 1 , and at the top by an erosive unconformity surface cropping out close to the summit (unconformity 2 in Fig. 4). The upper unconformity, geologically recent but unknown in age, has a sub-circular shape $(3.5 \times 3.9 \mathrm{~km})$ and may represent the margins of a caldera collapse, or the head of an important erosive amphitheatre in the summit area.
The upper unit (modern Kanlaon volcanics), representing the most recent products, overflows through three main depressions opened in $\mathrm{E}$ and $\mathrm{W}$ directions bounded by the unconformity 2 (Figs. 4 and 5). The main active vent, however, is located right on the southern rim of the unconformity 2 , reaching the highest elevation of the volcano, at $2435 \mathrm{~m}$ a.s.1.

The summit area of Kanlaon is characterized by a $5 \mathrm{~km}$ long, $0^{\circ} \mathrm{N}-30^{\circ}$ E-oriented elongated ridge made up of recent and morphologically well-preserved craters and eruptive fissures (Fig. 5). This ridge is surrounded to the $\mathrm{W}$ and $\mathrm{E}$ by three large deeply eroded topographic depressions, which correspond to portions of the unconformity 2 (Fig. 4). Eight craters or eruptive-related collapsed structures crop out in this area. The highest crater, active in recent decades, is located at the southernmost extremity of the ridge (AC; Fig. 5). A few hundred meters to the NE is the Lugad crater (LC; $1.5 \mathrm{~km}$ long and $0.8 \mathrm{~km}$ wide), followed to the $\mathrm{N}$ by an eruptive fissure, four smaller craters, and finally by the oldest well-preserved vents named Hardin Sang Balo nested craters 


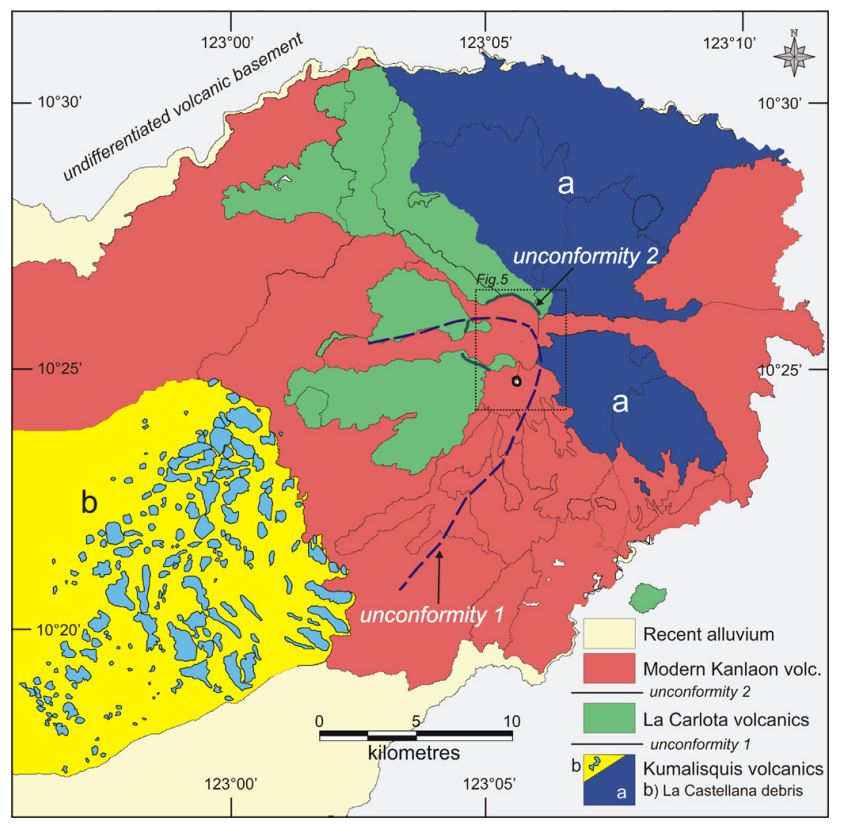

Fig. 4. Simplified geological map of Mt Kanlaon. La Castellana debris avalanche (a) is characterized by numerous and occasionally very large hummocks (up to $1.6 \mathrm{~km}^{2}$, highlighted in cyan) emerging in the matrix (in yellow); this deposit comes from the dismantling of the pre-existing volcanic edifice (Kumalisquis volcanics, in dark blue).

(two craters, HSBC; Fig. 5). Overall, these morphostructural features suggest a southward migration of the activity.

\subsection{Hazardous events, event tree and threat matrix}

To build an updated multi-hazard map at Kanlaon, we consider the hazardous events that are comprised in the following three categories:

- Sector collapses. At least once in its history $(\sim 0.4 \mathrm{Ma})$, Kanlaon was affected by a huge sector collapse. We considered this event as possible, even if it had occurred only once. However, a large sector collapse is highly improbable without significant modifications of the actual morphology (e.g. extensive fractures and landslides) and geophysical precursors. Therefore, mainly considering the very low frequency of occurrence, we neglected this in the present study.

- Eruptions. We distinguished effusive from explosive activities. Every eruption was then evaluated in terms of typology and frequency, considering the entire eruptive history of the volcano.

- Mudflows (lahars) induced by heavy rainfalls. Kanlaon is located in the equatorial belt, seasonally affected by heavy rainfall related to monsoons. Heavy rains



Fig. 5. Morphostructural analysis of the summit of Kanlaon volcano on a $10 \mathrm{~m}$ DEM. Arrows show the principal drainage paths. The summit area shows $0^{\circ} \mathrm{N}-30^{\circ}$ E-oriented craters and eruptive fissures. HSBC: Hardin Sang Balo crater; LC: Lugad crater; AC: active crater. See Fig. 4 for location.

during volcanic unrest producing major ash deposits can occasionally trigger landslides, avalanches and lahars that are potentially destructive and dangerous. Consequently, we considered "heavy rain" as hazardous events, or as a possible factor reinforcing hazardous volcanic events.

After identifying the type of hazardous events at Kanlaon and their possible frequencies and despite poor data available, we constructed the event tree shown in Fig. 6. Bearing in mind the historical information (covering almost the last $130 \mathrm{yr}$ ), we were able to infer only the frequency of the phreatic and phreatomagmatic activity, and a single effusive and Strombolian activity (see Table 6). Nevertheless, geologic studies evidenced that in the past the volcano was characterized by significant lava flow and pyroclastic deposit successions. Therefore, the occurrence probability of each event has been determined on the basis of the collected volcanological, geological, morphological and structural data and from the literature (Von Biedersee and Pichler, 1995).

The event tree begins with a "volcanic unrest" (e.g. seismic activity, gas emission, ground deformations) (Fig. 6), extending towards an initiation stage divided into two possibilities: "no sector collapse", and exceptionally, "sector 


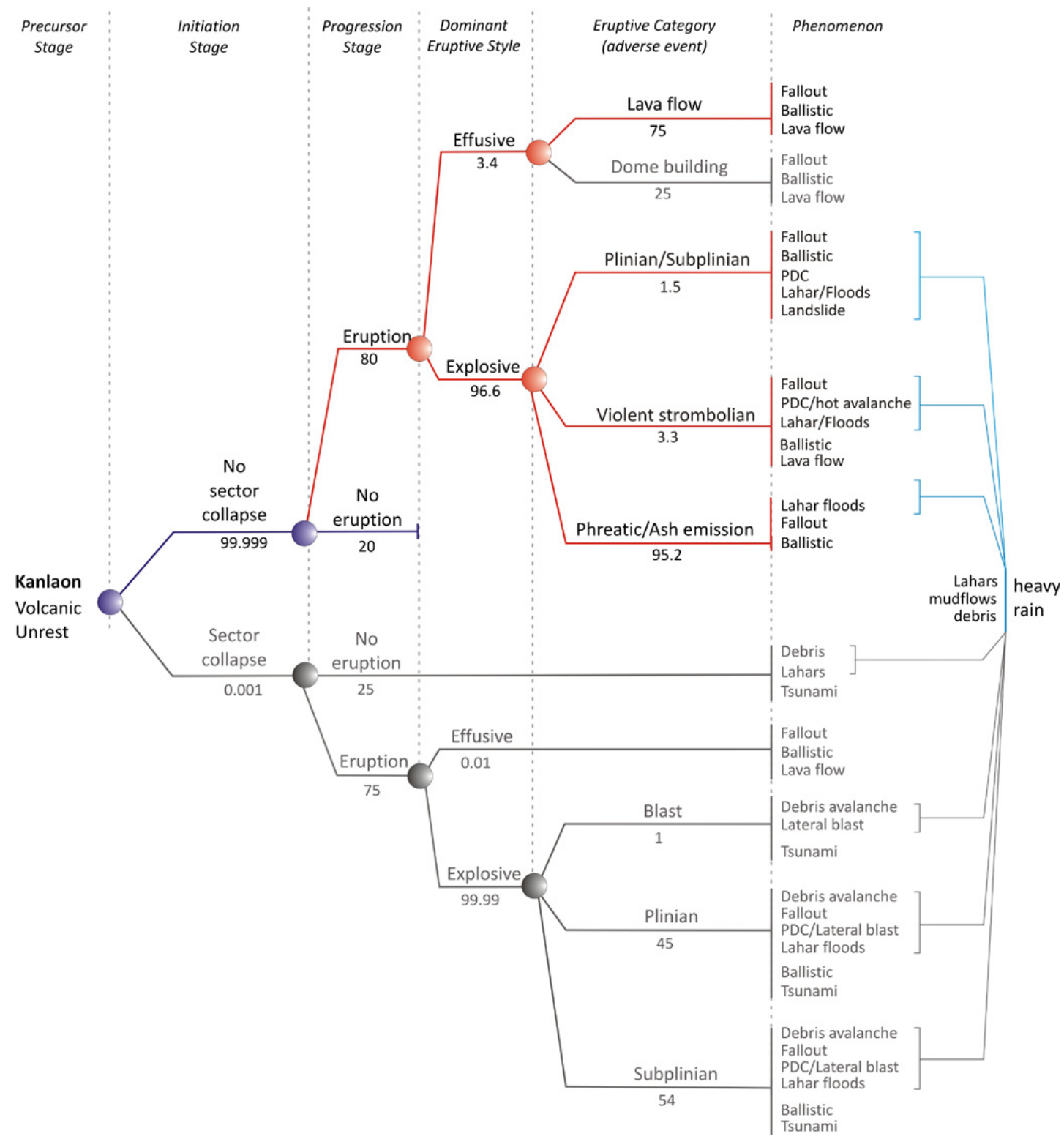

Fig. 6. Type of hazardous events and their possible frequencies at Kanlaon volcano. In grey are the parts of the tree occurring at Kanlaon so rarely as not permitting reliable statistical calculations.

collapse". We will focus in the following on the case of "no sector collapse". The tree develops into "eruption" or "no eruption". Then, the dominant eruptive style would very likely be "explosive" rather than "effusive" producing several eruptive categories and related phenomena.

The hazard of the phenomena highlighted in the event tree may increase dramatically during heavy rain periods, which characterize the region seasonally, as shown in the right portion of Fig. 6. Rain can remobilize unconsolidated volcanic deposits not only during an eruption, but also beyond the period of the eruption for several years, violently dragging them down until reaching a new morphological equilibrium.
Hence, we calculated a threat matrix for Kanlaon, where the different hazardous events are numerically evaluated on the basis of their frequencies and potential impacts. Also in this case, we found several difficulties because of the return period of several events that are unknown (e.g. pyroclastic flows, lahars). This made us consider the application of the method outlined in the first half of this paper as "flexible", in order to overcome the problem, by introducing several simplifications (i.e. combining several types of eruptions, such as Plinian and sub-Plinian) deriving from our knowledge applied to Kanlaon.

Since 1866, Kanlaon volcano has produced 29 eruptive events (Table 6), mainly explosive, including only one 
effusive eruption in 1902 (Siebert et al., 2010). This count may be underestimated due to the absence of constant monitoring activity, especially in the first half of the 20th century. Considering all the available data, the volcanic (eruptive) unrest $\left(R_{\mathrm{ur}}\right)$ is evaluated as

$R_{\mathrm{ur}}=(2012-1866) / 29$ events $=5 \mathrm{yr}$.

Assuming the probability of "no collapse" $\left(P_{\text {ncol }}=99.999\right)$ and "collapse" $\left(P_{\mathrm{col}}=0.001\right)$ events, the related return periods $(R)$ are

$$
\begin{aligned}
R_{\mathrm{ncol}} & =R_{\mathrm{ur}} \cdot\left(P_{\mathrm{ncol}}+P_{\mathrm{col}}\right) / P_{\mathrm{ncol}} \\
& =5 \cdot(99.999+0.001) / 99.99=5 \mathrm{yr}, \\
R_{\mathrm{col}} & =R_{\mathrm{ur}} \cdot\left(P_{\mathrm{ncol}}+P_{\mathrm{col}}\right) / P_{\mathrm{col}} \\
& =5 \cdot(99.999+0.001) / 0.001=503403 \mathrm{yr} .
\end{aligned}
$$

The latter value is based on one single collapse event and is thus not constrainable. In the case of volcanic unrest $\left(R_{\mathrm{u}}\right)$, we considered the probability of occurrence of the eruption $\left(P_{\mathrm{er}}=80 \%\right)$ and no eruption $\left(P_{\mathrm{ner}}=20 \%\right)$ based on the last $25 \mathrm{yr}$ of observations (PHIVOLCS reports available at http://www.phivolcs.dost.gov.ph/). Since 1866, only one effusive event has occurred (1902) out of a total of 29 events. Thus the probabilities of explosive and effusive events are $P_{\text {expl }}=28 / 29=96.6 \%$ and $P_{\text {eff }}=1 / 29=3.4 \%$, respectively (Fig. 6). We then calculated the related return periods $(R)$ of the eruptive events and the relative probabilities applying the likelihood table shown in ICPP (2012), scaling them on the baseline frequency scale (see Table 3):

$$
\begin{gathered}
R_{\mathrm{er}}=\left(R_{\mathrm{ncol}} \cdot 100\right) / P_{\mathrm{er}}=(5.03 \cdot 100) / 80=6.3 \mathrm{yr} \\
R_{\mathrm{ner}}=\left(R_{\mathrm{ncol}} \cdot 100\right) / P_{\mathrm{ner}}=(5.03 \cdot 100) / 20=25.2 \mathrm{yr} \\
R_{\mathrm{expl}}=\left(R_{\mathrm{er}} \cdot 100\right) / P_{\mathrm{expl}}=(6.3 \cdot 100) / 95.2=6.8 \mathrm{yr} \\
\Rightarrow R_{\mathrm{plinian} / \text { subplinian }}=(6.5 \cdot 100) / 1.5=434.4 \mathrm{yr} \\
\quad \Rightarrow F_{3} \text { Moderate } \\
\Rightarrow R_{\text {strombolian }}=(6.5 \cdot 100) / 3.3=197.4 \mathrm{yr} \\
\Rightarrow F_{3} \text { Moderate } \\
\Rightarrow R_{\text {ash } / \mathrm{phreatic}}=(6.5 \cdot 100) / 95.2=6.8 \mathrm{yr} \\
\Rightarrow F_{6} \text { Quasi Permanent } \\
R_{\mathrm{eff}}=\left(R_{\mathrm{er}} \cdot 100\right) / P_{\mathrm{eff}}=(6.3 \cdot 100) / 3.4=185.1 \mathrm{yr} \\
\Rightarrow R_{\text {lavaext }}=(185.1 \cdot 100) / 75=246.8 \mathrm{yr} \\
\Rightarrow F_{3} \text { Moderate },
\end{gathered}
$$

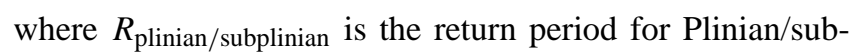
Plinian eruptions, $R_{\text {strombolian }}$ the return period for Strombolian eruptions, $R_{\text {ash/phreatic }}$ the return period for ash/phreatic eruptions, and $R_{\text {lavaext }}$ return period for lava eruptions. Combining the results using the indexes of Tables 2, 3, and 5, we obtain threat values for each phenomenon as shown in Table 7 .

\subsection{Multi-hazard map construction}

Thanks to the recently acquired new data on the geology and geomorphology of Kanlaon, we divide the volcano into several sectors, each of them corresponding to different probabilities of a given event to occur. Then, we provide a best estimate of the distance reached by each phenomenon, without attempting to provide a more sophisticated approach, due to the poor amount of available data.

We firstly took into account the existing lava hazard map, and the pyroclastic flow and lahar hazard map of Kanlaon edited by the Philippine Institute of Volcanology and Seismology (PHIVOLCS), both available at http://www.phivolcs. dost.gov.ph. Therefore, we revisited these documents, taking into account the results from a fieldwork overview and from the remote sensing data analysis (see Sect. 3). The resulting hazard maps related to lava flows, pyroclastic flows and mudflows (lahars) are shown in Fig. 7.

Figure 7a shows the areas prone to lava invasion. We distinguished two zones characterized by high and low hazard, respectively. The map is compiled considering the position of the active and potentially active summit vents, the morphology of the volcano and the characteristics of lava flows cropping out on its flanks. None of the cities and the villages are located in these areas.

Figure $7 \mathrm{~b}$ illustrates the zones potentially invaded by pyroclastic flows, mudflows and lahars, and potentially threatened by the fall of ballistic products due to phreatic and/or phreatomagmatic explosions erupted from the summit vents. The red line $4 \mathrm{~km}$ away from the summit vents circumscribes the area with greatest hazard, while the other contours mark zones with progressively less volcanic hazard. The longest pyroclastic flow is imaged to reach a maximum distance of about 10-12 km, along the southern half of the volcanic edifice, in agreement with field evidence (Von Biedersee and Pichler, 1995; http://www.phivolcs.dost.gov.ph). Moreover, we have plotted the drainage system on the map, highlighting the zones potentially affected by mudflows and lahars deriving from potentially violent and long-lasting rainfalls.

Superimposing all the volcanic and volcanic-derived hazards (e.g. mudflows, lahars), we generated a new map showing 13 areas characterized by different values of the threat index (Fig. 8a). This map represents the first draft of the multi-hazard map. The next step consists in defining prevention recommendations with the authorities. This requires refining the map using geological and morphological evidence, and grouping the values into a few multi-hazard classes, which should be linked with prevention recommendations. Although this step falls beyond the physical science assessment and the scope of this study, we second Cash et al. (2003) in acknowledging the importance of treating this step seriously. Here, we provide Fig. $8 \mathrm{~b}$ as an illustrative example based on our best estimate, with hazard classes ranging from negligible to very high. 
Table 7. Threat index calculated for each considered phenomenon.

\begin{tabular}{lccccc}
\hline Phenomenon & $\begin{array}{c}\text { Intensity } \\
\text { class }\end{array}$ & $\begin{array}{c}\text { Numerical } \\
\text { equivalent of } \\
\text { intensity } \\
\text { class }\end{array}$ & $\begin{array}{c}\text { Frequency } \\
\text { class }\end{array}$ & $\begin{array}{c}\text { Index } \\
\text { of } \\
\text { frequency } \\
\text { class }\end{array}$ & $\begin{array}{c}\text { Threat } \\
\text { index }\end{array}$ \\
\hline Plinian/Sub-Plinian eruptions & $I_{5}$ & 100 & $F_{3}$ & 0.2 & 20 \\
Strombolian eruptions & $I_{1}$ & 0.5 & $F_{3}$ & 0.2 & 0.1 \\
Phreatic/Ash eruptions & $I_{2}$ & 2.5 & $F_{6}$ & 10 & 25 \\
Effusive eruptions & $I_{1}$ & 0.5 & $F_{3}$ & 0.2 & 0.1 \\
\hline
\end{tabular}

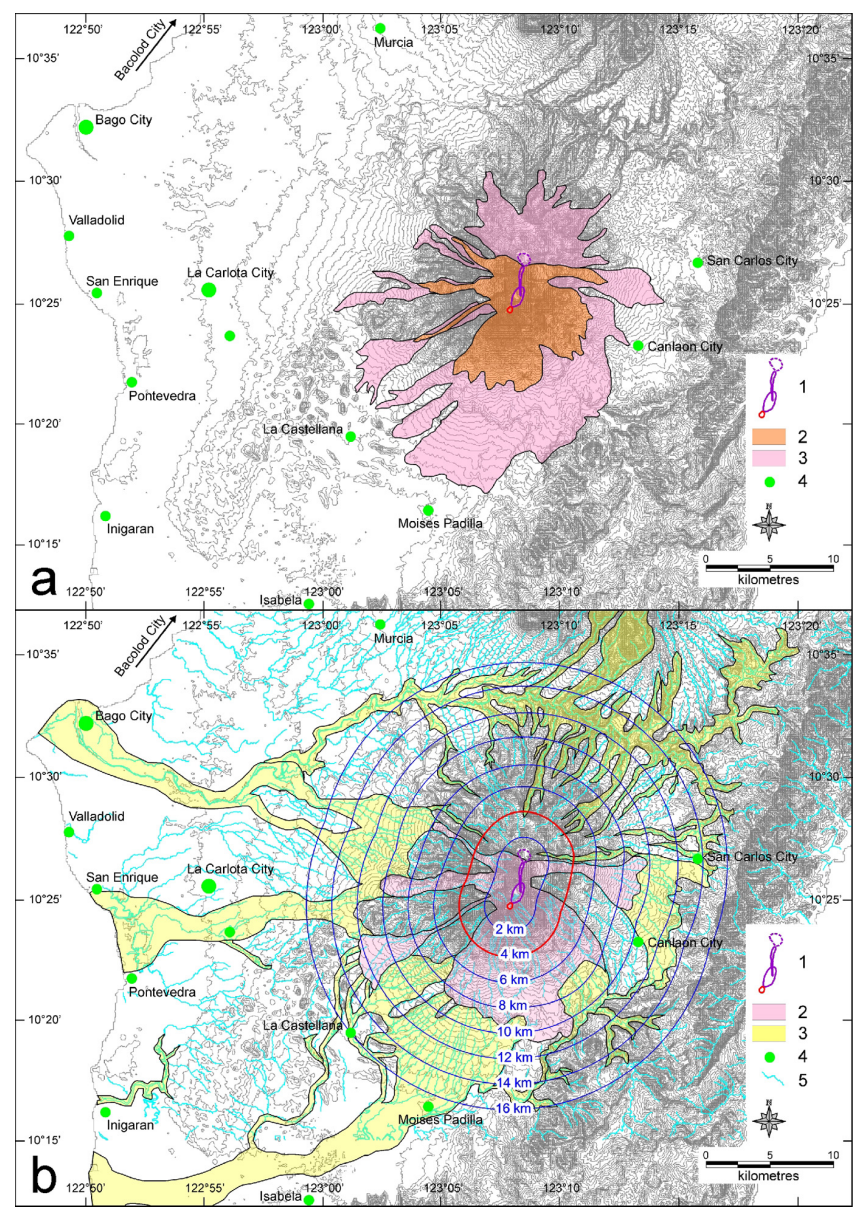

Fig. 7. Volcanic hazard map of Kanlaon (modified from http:// www.phivolcs.dost.gov.ph). (a) Lava hazard map: 1 - active summit vents; 2 - area prone to high hazard of lava invasion; 3 - area prone to slight hazard of lava invasion; 4 - main towns and villages. (b) Pyroclastic and lahar hazard map: 1 - active summit vents; 2 - areas highly prone to pyroclastic flows; 3 - areas highly prone to lahars; 4 - main towns and villages; 5 - drainage system. The elliptical blue lines show areas progressively further away from the summit active vent. The area within $4 \mathrm{~km}$ from the summit vents, highlighted in red, indicates the area of maximum volcanic hazard.

\section{Discussion}

In this paper, we propose a multi-hazard mapping method applied to Kanlaon, an active volcano with more than 300000 inhabitants in its vicinity, distributed in many villages located on its slopes, or close to the base of the volcano. The hazard assessment regarding the local population is, therefore, not a trivial exercise. We improve the previous existing hazard map by integrating new areas identified as prone to volcanic and volcanic-derived hazards. In particular, we redefined the summit active area by extending the potentially active area towards the north; we also define an overlooked area prone to potential mudflows and pyroclastic flows located on the eastern side of the volcano.

Kanlaon volcano is characterized by two main concerns: (1) its eruptive activity is poorly understood and rather uneven over time; and (2) the volcano is located in a subequatorial climate zone, namely in an area characterized by seasonally abundant and violent rainfall, able to mobilize materials deposited during previous eruptions (e.g. ashfall) and to generate almost instantly voluminous lahars, debris and mudflows.

\subsection{Limitations}

The main limitation consists in the lack of knowledge of the timing of volcanic phenomena. Geological knowledge of Kanlaon is incomplete and still needs improvement, especially for mudflow and lahar mapping. Using existing incomplete data allows broadly deciphering the type and extent of eruptive phenomena at Kanlaon, and their overall stratigraphy. However, very few time markers are available in the stratigraphic succession. Therefore, the main difficulty is to determine the occurrence frequency of each geological event.

The structure of the event tree shown in Fig. 6 is essentially the result of experts' best guesses based on geological knowledge (first-order stratigraphy and vent repartition at the summit), and on the recent volcanic unrest $(<120 \mathrm{yr})$. The resulting event tree, which depends heavily on the operator applying the method, provides values that are potentially affected by large errors due to considerable unknowns. Under these conditions, we should consider the phenomena in their 


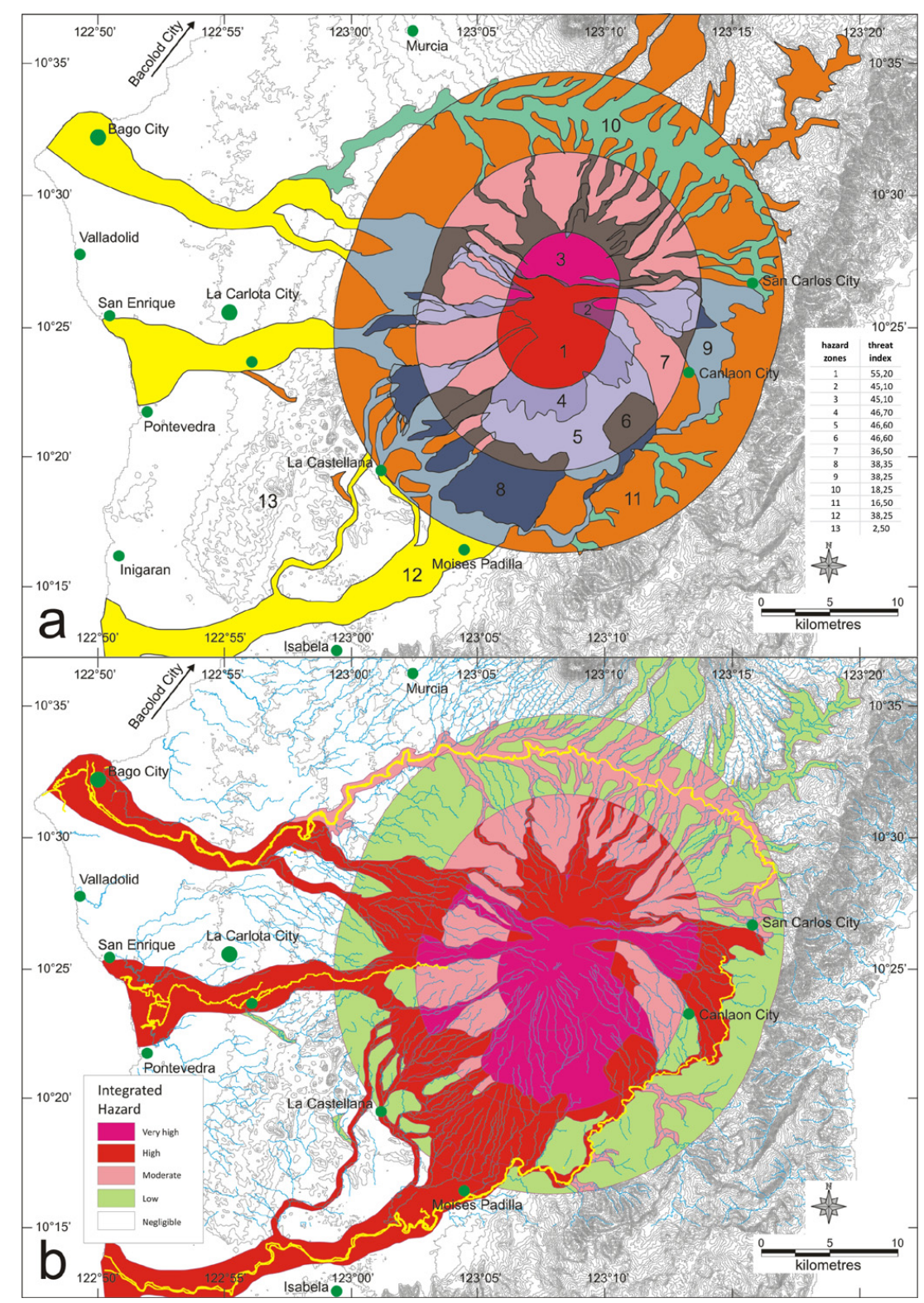

Fig. 8. Multi-hazard map of Kanlaon. (a) Preliminary map obtained by overlapping the values of threat index for each phenomenon in different sectors of the analysed territory. (b) Final multi-hazard map obtained by grouping the threat indexes into five classes. See text for explanation. Blue lines represent the drainage system (in yellow are the main rivers potentially affected by huge lahar and mudflow deposits).

largest spatial and temporal extents, in favour of safety. Such basic hazard maps must of course be modified in the case of future unrest, and might be adapted according to ongoing activity, integrating all available data (e.g. seismicity, ground deformation, etc.).

This methodological application is still lacking in up-todate detailed topographic data, especially in areas with extensive vegetation. In the case of Kanlaon, this problem has been at least partially overcome by using a new DEM with a good accuracy relative to the summit of the volcano $(10 \mathrm{~m}$ resolution), which allowed us to better understand the morphostructural features of the currently or recently active erup- tive vents. This new DEM may also allow future modelling of lava flows and mudflows potentially affecting the volcano surroundings.

\subsection{Implications for people at risk}

Turning to the map shown in Fig. 8b, it is clear that the high slopes of the volcano $(0-4 \mathrm{~km}$ away from the summit vents) are characterized by the greatest level of hazard.

The medium slopes of the volcano (4-10 km away from the summit vents) are characterized by a rather high level of hazard, ranging from moderate (to the $\mathrm{N}$ ) to very high (to 
the $\mathrm{S}$ ). This hazard is mainly due to potential volcanic activity, and obviously decreases with greater distance from the summit active vents.

At distances of more than $10 \mathrm{~km}$ from the summit area, the most hazardous areas fall along almost all the courses of major rivers and streams (Fig. 8). There are three main rivers, two of which are fairly long, bounding the volcano to the $\mathrm{N}, \mathrm{S}$ and $\mathrm{E}$, draining the water towards the $\mathrm{W}$ until the sea coast. Along these rivers the highest hazard may be produced by lahar phenomena combined with volcanic phenomena (pyroclastic flows). Again, heavy rains can swell rivers, thereby triggering dangerous alluvial events and/or voluminous lahars, mudflows and landslides. The latter phenomena can also occur irrespective of the eruptive activity, due to the regular frequency characterizing the intense rainfall in sub-equatorial regions. The resident population living on the slopes and at the base of the volcano amounts to a total of more than 300000 people; some urban areas fall within or are close to areas with moderate to high hazard (Bago City, St Charles City, Moises Padilla, San Enrique, La Castellana, La Carlota City), for a total of approximately 50000 inhabitants.

\subsection{Relevance and adaptability of the approach to other contexts}

Multiple kinds of adverse events may typically occur at volcanoes. In such areas, evaluations of the various threats that are not cross-referenced may lead to inappropriate hazard mapping and land use planning recommendations (Bell and Glade, 2004). The key point in holistic multi-hazard mapping methods is thus a common baseline upon which the various threats can be evaluated. Here, we proposed a common baseline based on potential impacts of each adverse event. This baseline provides a reference scale for assessing the frequency and intensity of each kind of hazard at each location, thus making the comparison of threats possible. While this issue is particularly critical in volcanic areas, it may also be applied to a wide range of natural and human hazards.

One limitation of the multi-hazard mapping approach presented in Thierry et al. (2008) was its complex applicability to volcanoes having many different eruption modes. Implicitly, a limited number of eruptive modes were considered in mapping the hazards at Mount Cameroon, including the most probable effusive modes and the unlikely large-scale debris avalanche and phreatomagmatic eruption (plus other adverse events such as landslides). In more complex volcanoes, considering the probabilities associated with each eruption requires a more formalized approach. We found that the event tree approach (Newhall and Hoblitt, 2002) proved highly appropriate to this end. We believe that this structured approach toward various eruptive scenarios enables the application of this hazard mapping method to other poorly studied volcanic areas, as a first-order hazard estimate.
There is undoubtedly much added value in applying advanced numerical modelling to further refine hazard mapping (e.g. Macías et al., 2008). However, these modelling exercises should not only address the maximal extent or possible intensity of adverse events. They should also provide some insight into their frequency of occurrence (e.g. Favalli et al., 2012). Finally, given the multiplicity of threats affecting volcanic areas, producing a complete multi-hazard map will require a combination of advanced modelling approaches together with sometimes approximate approaches.

The resulting multi-hazard maps could be used for raising public awareness, together with other tools, e.g. for alert decision support (Aspinall et al., 2006). However, Haynes et al. (2007) showed they may not be sufficient to help people to comprehend the spatial significance of the actual threats. For this wider user application, participatory methods are probably needed in addition to knowledge of the hazards (e.g. Cronin et al., 2004). In effect, the main purpose of such multi-hazard maps is to help local authorities and civil defence make more conscious land use planning decisions. For these users, we believe that such multi-hazard maps are a significant improvement to susceptibility maps, because they relate practical and understandable recommendations to the various levels of threats. However, in order to effectively serve disaster mitigation, the generic recommendations associated with each threat level in the hazard map (Table 5) should be adapted to the local context (e.g. geographical, cultural and social, etc.), which was not undertaken within this methodological study.

\section{Conclusions}

The proposed method for volcanic hazard mapping has been applied to the Kanlaon volcano in the Philippines. We implement previous geological knowledge together with a new analysis of remote sensing images and fieldwork, providing (1) a first-order stratigraphy succession and (2) a detailed morphostructural analysis of the summit area. These results, together with historical records of volcanic activity, allowed us to elaborate on a simplified event tree of potential hazards affecting Kanlaon, and to provide an updated multi-hazard map of the volcano. In the light of the limitations from poor geological and historical records, the proposed semi-quantitative methodology should be applied with flexibility, enabling an update of the hazard map during future unrest. This study shows that the lack of data firstly affects our ability to define the frequency of events. In order to reduce uncertainty, it is necessary to focus on future geological studies establishing a chronology and collecting information on previous events. Detailed mudflow and lahar deposits are a key issue all around Kanlaon, especially on the E side of the volcano, which is densely populated but still poorly studied. 
Beyond their limitation on the application at Kanlaon, the obtained results constitute a useful enhancement of the already existing hazard maps. The proposed multi-hazard method was found to produce maps that are relevant towards land use planning. We believe that this approach is pertinent and may be applied to other poorly known volcanic areas and possibly in more generic multi-hazard assessments.

Acknowledgements. This work was undertaken under the MIAVITA project, financed by the European Commission under the 7th Framework Programme for Research and Technological Development, Area "Environment", Activity 6.1 "Climate Change, Pollution and Risks". The authors would like to thank A. Vagner, J. Douglas, P. Gehl, J. Loiseau and E. Vanoudheusden for useful comments that led to the improvement of the proposed method. Very special thanks go to PHIVOLCS and particularly V. Antonia Bornas, M. Martinez-Villegas M. and E. Bariso for the invaluable support during fieldwork, and highly useful discussions on the geology of Kanlaon. S. Conway has improved the English language. We thank Dmitri Rouwet and two anonymous reviewers for their constructive comments that greatly improved the paper.

Edited by: A. Costa

Reviewed by: D. Rouwet and two anonymous referees

\section{References}

Acocella, V., Porreca, M., Neri, M., Mattei, M., and Funiciello, R.: Fissure eruptions at Mount Vesuvius (Italy): insights on the shallow propagation of dikes at volcanoes, Geology, 34, 673-676, doi:10.1130/G22552.1, 2006a.

Acocella, V., Neri, M., and Scarlato, P.: Understanding shallow magma emplacement at volcanoes: Orthogonal feeder dikes during the 2002-2003 Stromboli (Italy) eruption, Geophys. Res. Lett., 33, L17310, doi:10.1029/2006GL026862, 2006b.

Aspinall, W. P.: Structured elicitation of expert judgment and its use for probabilistic hazard and risk assessment in volcanic eruptions, in: Statistics in Volcanology, edited by: Mader, H. M., Coles, S. G., Connor, C. B., and Connor, L. J., Geol. Soc. London, International Association of Volcanology and Chemistry of the Earth's Interior, IAVCEI Publications, London, 1-268, 2006.

Aspinall, W. P., Carniel, R., Jaquet, O., Woo, G., and Hincks, T.: Using hidden multi-state Markov models with multi-parameter volcanic data to provide empirical evidence for alert level decision-support, J. Volcanol. Geoth. Res., 153, 112-124, doi:10.1016/j.jvolgeores.2005.08.010, 2006.

Ayonghe, S. N., Ntasin, E. B., Samalang, P., and Suh, C. E.: The June 27, 2001 landslide on volcanic cones in Limbe, Mount Cameroon, West Africa, J. Afr. Earth Sci., 39, 435-439, 10.1016/j.jafrearsci.2004.07.022, 2004.

Barreca, G., Bonforte, A., and Neri, M.: A pilot GIS database of active faults of Mt. Etna (Sicily): A tool for integrated hazard evaluation, J. Volcanol. Geoth. Res., 251, 170-186, doi:10.1016/j.jvolgeores.2012.08.013, 2013.

Bell, R. and Glade, T.: Multi-hazard analysis in natural risk assessments, in: Risk Analysis IV, edited by: Brebbia, C. A., WIT Press Southampton, 197-206, doi:10.2495/RISK040181, 2004.
Bignami, C., Ruch. J., Chini, M., Neri, M., and Buongiorno, F.: Pyroclastic density current volume estimation after the 2010 Merapi volcano eruption using X-band SAR, J. Volcanol. Geoth. Res., doi:10.1016/j.jvolgeores.2013.03.023, in press, 2013.

Boiteux, M. and Baumstark, L.: Transport: choix des investissements et coût des nuisances, Report, Commissariat Général $\mathrm{du}$ Plan, La Documentation française, Paris, France, 328 pp., available at: http://www.ladocumentationfrancaise.fr/var/ storage/rapports-publics/014000434/0000.pdf, last access: July 2013, 2001 (in French).

Cash, D. W., Clark, W. C., Alcock, F., Dickson, N. M., Eckley, N., Guston, D. H., Jager, J., and Mitchell, R. B.: Knowledge systems for sustainable development, P. Natl. Acad. Sci. USA, 100, 80868091, doi:10.1073/pnas.1231332100, 2003.

Crisci, G. M., Avolio, M. V., Behncke, B., D’Ambrosio, D., Di Gregorio, S., Lupiano, V., Neri, M., Rongo, R., and Spataro, W.: Predicting the impact of lava flows at Mount Etna, Italy, J. Geophys. Res., 115, B04203, doi:10.1029/2009jb006431, 2010.

Cronin, S. J., Gaylord, D. R., Charley, D., Alloway, B. V., Wallez, S., and Esau, J. W.: Participatory methods of incorporating scientific with traditional knowledge for volcanic hazard management on Ambae Island, Vanuatu, B. Volcanol., 66, 652-668, doi:10.1007/s00445-004-0347-9, 2004.

Douglas, J.: Physical vulnerability modelling in natural hazard risk assessment, Nat. Hazards Earth Syst. Sci., 7, 283-288, doi:10.5194/nhess-7-283-2007, 2007.

Favalli, M., Tarquini, S., Papale, P., Fornaciai, A., and Boschi, E.: Lava flow hazard and risk at Mt. Cameroon volcano, B. Volcanol., 74, 423-439, doi:10.1007/s00445-011-0540-6, 2012.

Grunthal, G., Thieken, A. H., Schwarz, J., Radtke, K. S., Smolka, A., and Merz, B.: Comparative risk assessments for the city of Cologne - Storms, floods, earthquakes, Nat. Hazards, 38, 21-44, doi:10.1007/s11069-005-8598-0, 2006.

Gurioli, L., Sulpizio, R., Cioni, R., Sbrana, A., Santacroce, R., Luperini, W., and Andronico, D.: Pyroclastic flow hazard assessment at Somma-Vesuvius based on the geological record, B. Volcanol., 72, 1021-1038, doi:10.1007/s00445-010-0379-2, 2010.

Hayes, S. K., Montgomery, D. R., and Newhall, C. G.: Fluvial sediment transport and deposition following the 1991 eruption of Mount Pinatubo, Geomorphology, 45, 211-224, doi:10.1016/s0169-555x(01)00155-6, 2002.

Haynes, K., Barclay, J., and Pidgeon, N.: Volcanic hazard communication using maps: an evaluation of their effectiveness, B. Volcanol., 70, 123-138, doi:10.1007/s00445-007-0124-7, 2007.

IPCC: Managing the Risks of Extreme Events and Disasters to Advance Climate Change Adaptation, A Special Report of Working Groups I and II of the Intergovernmental Panel on Climate Change, edited by: Field, C. B., Barros, V., Stocker, T. F., Qin, D., Dokken, D. J., Ebi, K. L., Mastrandrea, M. D., Mach, K. J., Plattner, G.-K., Allen, S. K., Tignor, M., and Midgley, P. M., Cambridge University Press, Cambridge, UK, and New York, NY, USA, 582 pp., 2012.

Kappes, M. S., Keiler, M., von Elverfeldt, K., and Glade, T.: Challenges of analyzing multi-hazard risk: a review, Nat. Hazards, 64, 1925-1958, doi:10.1007/s11069-012-0294-2, 2012.

Klose, C. D.: Health risk analysis of volcanic $\mathrm{SO}_{2}$ hazard on Vulcano Island (Italy), Nat. Hazards, 43, 303-317, doi:10.1007/s11069-007-9115-4, 2007. 
Lavigne, F., de Bélizal, E., Cholik, N., Aisyah, N., Picquout, A., and Tyas Wulan Mei, E.: Lahar hazards and risks following the 2010 eruption of Merapi volcano, Indonesia, EGU General Assembly, Vienna, Austria, 3-8 April 2011, EGU2011-4400, 2011.

Macías, J. L., Capra, L., Arce, J. L., Espindola, J. M., GarciaPalomo, A., and Sheridan, M. F.: Hazard map of El Chichón volcano, Chiapas, México: Constraints posed by eruptive history and computer simulations, J. Volcanol. Geoth. Rese., 175, 444458, doi:10.1016/j.jvolgeores.2008.02.023, 2008.

Martì, J., Aspinall, W. P., Sobradelo, R., Felpeto, A., Geyer, A., Ortiz, R., Baxter, P., Cole, P., Pacheco, J., Blanco, M. J., and Lopez, C.: A long-term volcanic hazard event tree for Teide-Pico Viejo stratovolcanoes (Tenerife, Canary Islands), J. Volcanol. Geoth. Res., 178, 543-552, doi:10.1016/j.jvolgeores.2008.09.023, 2008.

Marzocchi, W. and Woo, G.: Principles of volcanic risk metrics: Theory and the case study of Mount Vesuvius and Campi Flegrei, Italy, J. Geophys. Res., 114, B03213, doi:10.1029/2008jb005908, 2009.

Marzocchi, W., Sandri, L., Gasparini, P., Newhall, C., and Boschi, E.: Quantifying probabilities of volcanic events: The example of volcanic hazard at Mount Vesuvius, J. Geophys. Res., 109, B11201, doi:10.1029/2004jb003155, 2004

Marzocchi, W., Mastellone, M. L., Di Ruocco, A., Novelli, P., Romeo, E., and Gasparini, P.: Principles of multi-risk assessment, Interaction amongst natural and man induced risks, European Commission EUR23615, Brussels, Belgium, 72 pp., 2009.

Marzocchi W., Sandri L., and Selva J.: BET_VH: a probabilistic tool for long-term volcanic hazard assessment, B. Volcanol., 72, 717-733, doi:10.1007/s00445-010-0358-7, 2010.

Neri, A., Aspinall, W. P., Cioni, R., Bertagnini, A., Baxter, P. J., Zuccaro, G., Andronico, D., Barsotti, S., Cole, P. D., Ongaro, T. E., Hincks, T. K., Macedonio, G., Papale, P., Rosi, M., Santacroce, R., and Woo, G.: Developing an Event Tree for probabilistic hazard and risk assessment at Vesuvius, J. Volcanol. Geoth. Res., 178, 397-415, 10.1016/j.jvolgeores.2008.05.014, 2008

Neri, M., Lanzafame, G., and Acocella, V.: Dike emplacement and related hazard in volcanoes with sector collapse: the 2007 Stromboli eruption, J. Geol. Soc. London, 165, 883-886, doi:10.1144/0016-76492008-002, 2008.

Newhall, C. G. and Hoblitt, R. P.: Constructing event trees for volcanic crises, B. Volcanol., 64, 3-20, doi:10.1007/s004450100173, 2002.

Newhall, C. G. and Self, S.: The Volcanic Explosivity Index (VEI) An Estimate of Explosive Magnitude for Historical Volcanism, J. Geophys. Res., 87, 1231-1238, doi:10.1029/JC087iC02p01231, 1982.

Rae, A. J., Cooke, D. R., Phillips, D., and Zaide-Delfin, M.: The nature of magmatism at Palinpinon geothermal field, $\mathrm{Ne}$ gros Island, Philippines: implications for geothermal activity and regional tectonics, J. Volcanol. Geoth. Res., 129, 321-342, doi:10.1016/s0377-0273(03)00280-4, 2004.
Sandri, L., Jolly, G., Lindsay, J., Howe, T., and Marzocchi, W.: Combining long- and short-term probabilistic volcanic hazard assessment with cost-benefit analysis to support decision making in a volcanic crisis from the Auckland Volcanic Field, New Zealand, B. Volcanol., 74, 705-723, doi:10.1007/s00445-0110556-y, 2012.

Selva, J., Costa, A., Marzocchi, W., and Sandri, L.: BET_VH: exploring the influence of natural uncertainties on long-term hazard from tephra fallout at Campi Flegrei (Italy), B. Volcanol., 72, 717-733, doi:10.1007/s00445-010-0358-7, 2010.

Siebert, L., Simkin, T., and Kimberly, P.: Volcanoes of the World. Smithsonian Institution, Washington D.C., University of California Press, 551 pp., 2010.

Simkin, T., Siebert, L., McClelland, L., Bridge, D., Newhall, C., and Latter, J. H.: Volcanoes of the World, Smithsonian Institution, Hutchinson Ross, Pennsylvania, USA, 1981.

Solaro, G., Acocella, V., Pepe, S., Ruch, J., Neri, M., and Sansosti, E.: Anatomy of an unstable volcano from InSAR: Multiple processes affecting flank instability at Mt. Etna, 1994-2008, J. Geophys. Res., 115, B10405, doi:10.1029/2009jb000820, 2010.

Solidum, R. U., Castillo, P. R., and Hawkins, J. W.: Geochemistry of lavas from Negros Arc, west central Philippines: Insights into the contribution from the subducting slab, Geochem. Geophy. Geosy., 4, 9008, doi:10.1029/2003gc000513, 2003.

Spence, R. J. S., Kelman, I., Baxter, P. J., Zuccaro, G., and Petrazzuoli, S.: Residential building and occupant vulnerability to tephra fall, Nat. Hazards Earth Syst. Sci., 5, 477-494, doi:10.5194/nhess-5-477-2005, 2005.

Stieltjes, L.: Vulnérabilité aux phénomènes volcaniques: méthodologie et évaluation. Application à la Martinique: rapport d'étape 1997, BRGM Report R39735, Orléans, France, 205 pp., 1997 (in French).

Thierry, P., Stieltjes, L., Kouokam, E., Ngueya, P., and Salley, P. M.: Multi-hazard risk mapping and assessment on an active volcano: the GRINP project at Mount Cameroon, Nat. Hazards, 45, 429456, doi:10.1007/s11069-007-9177-3, 2008.

Vecchia, A. V.: A unified approach to probabilistic risk assessments for earthquakes, floods, landslides, and volcanoes, in: Proceedings of a multidiscipilinary workshop held in Golden, Colorado November 16-17, 1999, Open-File Report 01-324, US Geological Survey, 2001.

Vicari, A., Ganci, G., Behncke, B., Cappello, A., Neri, M., and Del Negro, C.: Near-real-time forecasting of lava flow hazards during the 12-13 January 2011 Etna eruption, Geophys. Res. Lett., 38, L13317, doi:10.1029/2011g1047545, 2011.

Von Biedersee, H. and Pichler, H.: The Canlaon and its neighboring volcanos in the Negros Belt Philipines, J. Southe. Asian Earth, 11, 111-123, doi:10.1016/0743-9547(94)00042-d, 1995.

Zogning, A.: Le Mont Cameroun, un volcan actif: contribution à l'étude de géographie physique appliquée, Thèse de Doctorat de $3^{\mathrm{e}}$ cycle, Univ. Yaoundé, 447 pp., 1988 (in French). 